\title{
Algae Production from Wastewater Resources: An Engineering and Cost Analysis
}

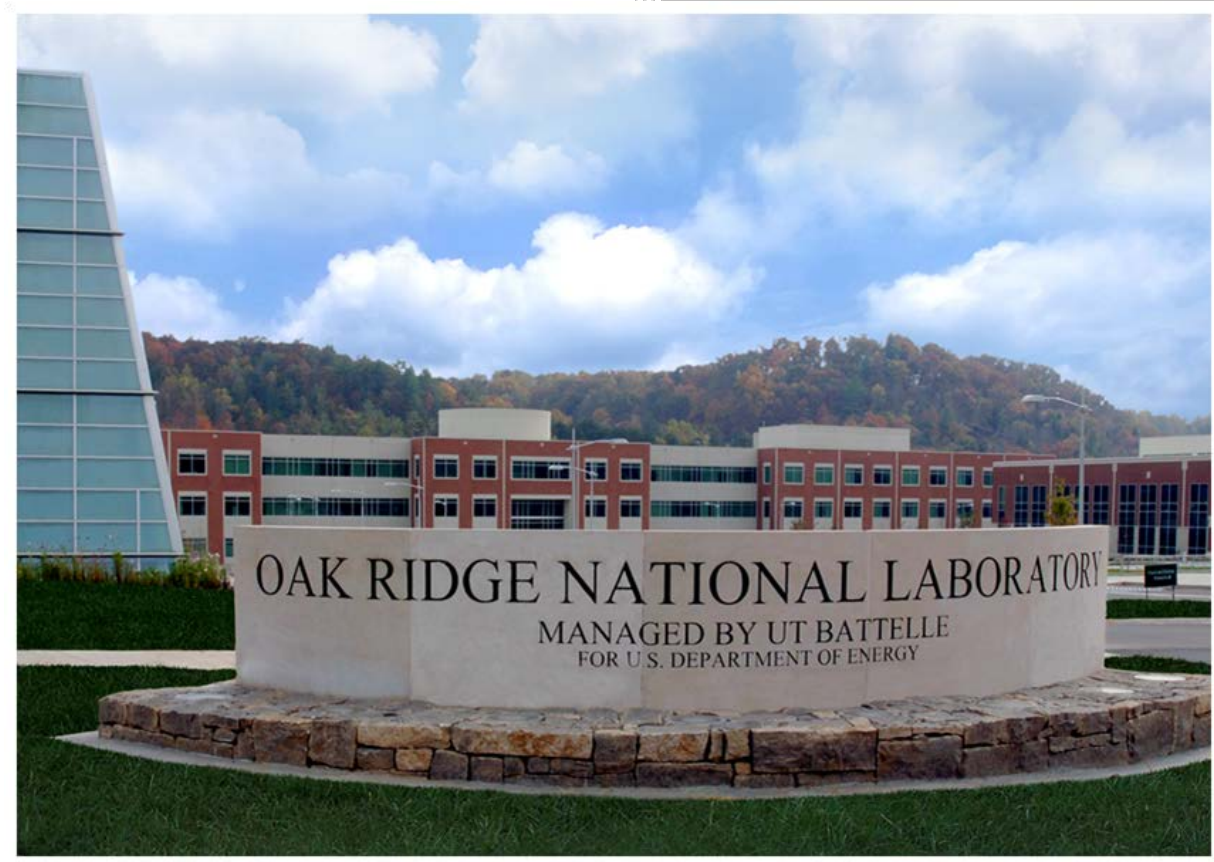

Approved for public release.

Distribution is unlimited.
Susan M. Schoenung Rebecca A. Efroymson

February 28, 2018 


\title{
DOCUMENT AVAILABILITY
}

Reports produced after January 1, 1996, are generally available free via US Department of Energy (DOE) SciTech Connect.

\section{Website http://www.osti.gov/scitech/}

Reports produced before January 1, 1996, may be purchased by members of the public from the following source:

\author{
National Technical Information Service \\ 5285 Port Royal Road \\ Springfield, VA 22161 \\ Telephone 703-605-6000 (1-800-553-6847) \\ TDD 703-487-4639 \\ Fax 703-605-6900 \\ E-mail info@ntis.gov \\ Website http://classic.ntis.gov/
}

Reports are available to DOE employees, DOE contractors, Energy Technology Data Exchange representatives, and International Nuclear Information System representatives from the following source:

Office of Scientific and Technical Information

PO Box 62

Oak Ridge, TN 37831

Telephone 865-576-8401

Fax 865-576-5728

E-mail reports@osti.gov

Website http://www.osti.gov/contact.html

This report was prepared as an account of work sponsored by an agency of the United States Government. Neither the United States Government nor any agency thereof, nor any of their employees, makes any warranty, express or implied, or assumes any legal liability or responsibility for the accuracy, completeness, or usefulness of any information, apparatus, product, or process disclosed, or represents that its use would not infringe privately owned rights. Reference herein to any specific commercial product, process, or service by trade name, trademark, manufacturer, or otherwise, does not necessarily constitute or imply its endorsement, recommendation, or favoring by the United States Government or any agency thereof. The views and opinions of authors expressed herein do not necessarily state or reflect those of the United States Government or any agency thereof. 
Environmental Sciences Division

\section{Algae Production from Wastewater Resources: An Engineering and Cost Analysis}

Susan M. Schoenung, Longitude 122 West, Inc.

Rebecca A. Efroymson, Oak Ridge National Laboratory

Date Published: January 15, 2018

Prepared by

OAK RIDGE NATIONAL LABORATORY

Oak Ridge, TN 37831-6283

managed by

UT-BATTELLE, LLC

for the

US DEPARTMENT OF ENERGY

under contract DE-AC05-00OR22725 



\section{CONTENTS}

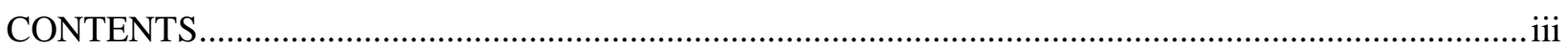

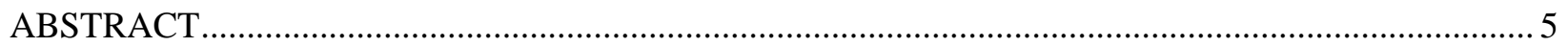

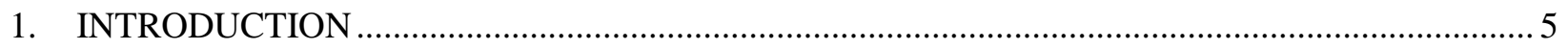

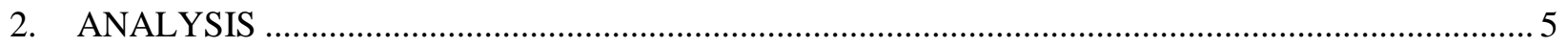

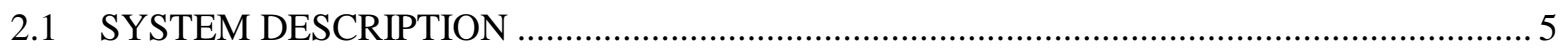

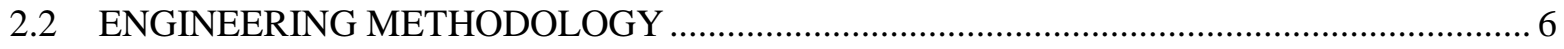

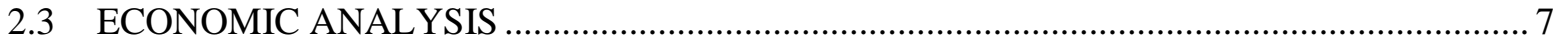

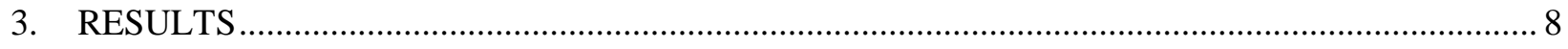

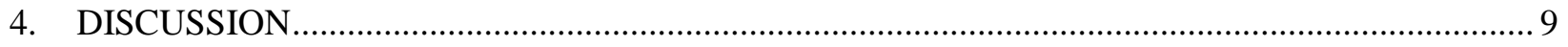

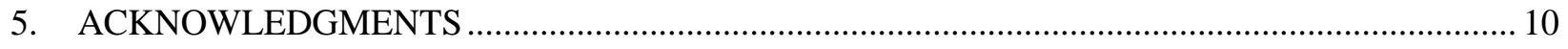

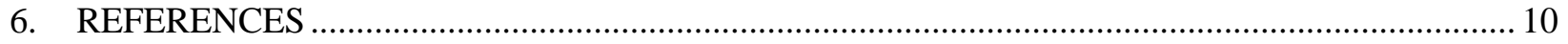




\begin{abstract}
Co-locating algae cultivation ponds near municipal wastewater (MWW) facilities provides the opportunity to make use of the nitrogen and phosphorus compounds in the wastewater as nutrient sources for the algae. This use potentially benefits MWW facilities, the algae biomass and biofuel or bioproduct industry, and the users of streams where wastewater would be discharged. Nutrient compounds can lead to eutrophication, hypoxia, and adverse effects to some organisms if released downstream. This analysis presents an estimate of the cost savings made possible to cultivation facilities by using the nutrients from wastewater for algae growth rather than purchase of the nutrients. The analysis takes into consideration the cost of pipe transport from the wastewater facility to the algae ponds, a cost factor that has not been publicly documented in the past. The results show that the savings in nutrient costs can support a wastewater transport distance up to 10 miles for a 1000-acre-pond facility, with potential adjustments for different operating assumptions.
\end{abstract}

\title{
1. INTRODUCTION
}

Microalgae are a potential source of liquid biofuels and bioproducts, but production of algae is costly. As discussed by Lundquist, Benemann and others [1][2][3][4], one of the advantages of co-locating algae cultivation ponds near municipal wastewater (MWW) facilities is the opportunity to make use of the nitrogen and phosphorus compounds in the wastewater to feed the algae. This co-location can provide benefits to algae production, wastewater treatment, and downstream stakeholders, as compounds in the wastewater can be directly toxic to organisms downstream or can lead to hypoxia [5][6], but they can serve as nutrients to the algae in cultivation facilities [7].

This analysis presents an estimate of the cost savings made possible by using the nutrients from wastewater for algae growth, compared to the purchase of nutrients. The analysis takes into consideration the cost of pipe transport from the wastewater facility to the algae ponds, a topic previously undocumented in scientific literature [8]. Additional benefits, such as carbon removal [9], are excluded from the analysis. Some previous studies of the topic of co-location assume that the wastewater treatment and biofuel generation are at the same site [9].

\section{ANALYSIS}

\subsection{SYSTEM DESCRIPTION}

Figure 1 is a simple depiction of the system analyzed. All preprocessing of the wastewater takes place prior to transport to the algae ponds. The transport system consists of pipeline and hydraulic pump. Electric power for the pump is provided at the origin. 


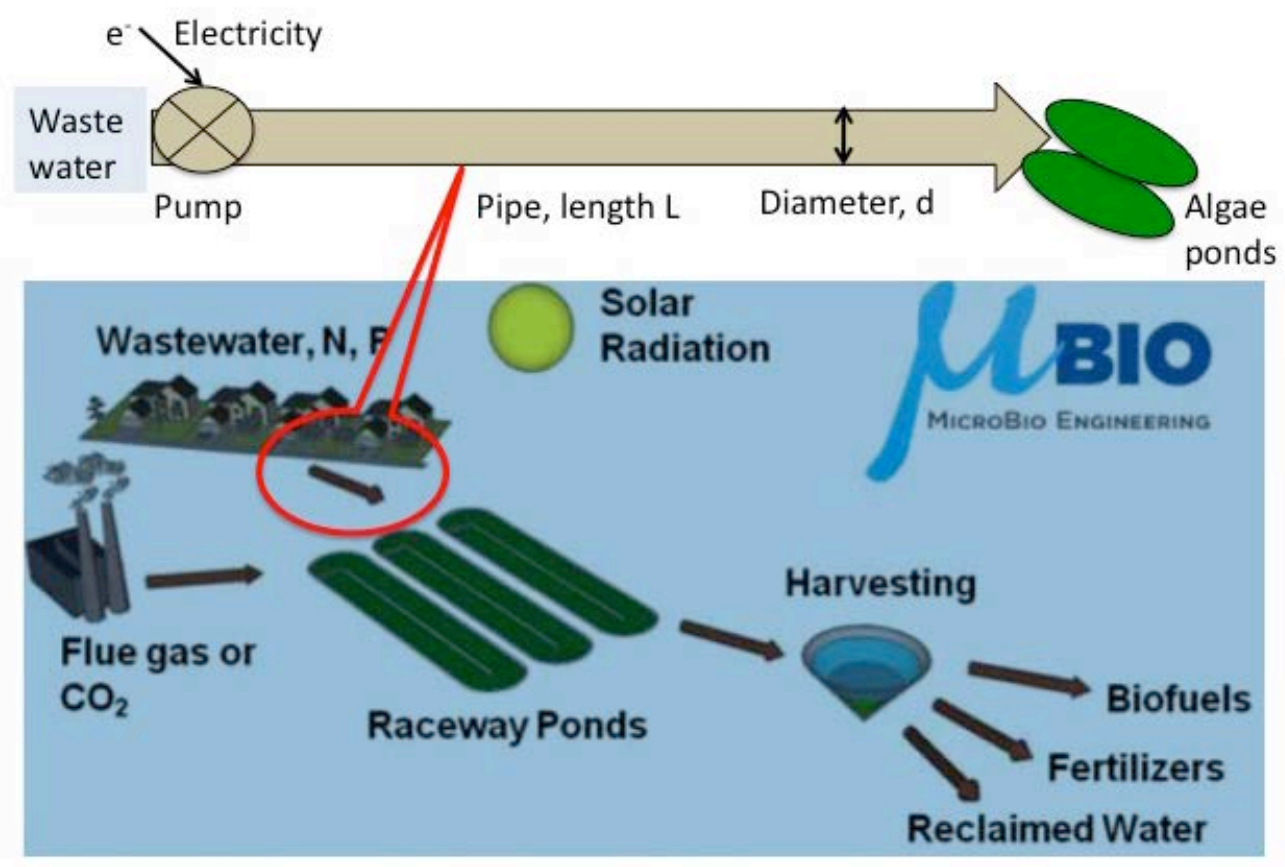

Figure 1. Simple depiction of a wastewater transport system for an open-pond algae production system, based on a MicroBio Engineering approach [10]. Used with permission from Microbio Engineering, Inc.

Basic assumptions for the size of the system are based primarily on the United States Department of Energy-supported research of Lundquist, Benemann and colleagues [11]. To take advantage of economies of scale, these authors assume a relatively large facility consisting of 1000 acres of algae ponds making use of 14 million gallons per day of wastewater influent. This volume of wastewater represents the typical effluent from a population of 80,000 people [12]. The algae system assumptions for this study are listed in Table 1.

Table 1. Algae system assumptions used in the engineering and cost analysis for wastewater transport to an open-pond algae cultivation system.

\begin{tabular}{|l|l|l|}
\hline \multicolumn{1}{|c|}{ Parameter } & \multicolumn{1}{c|}{ Value } & \multicolumn{1}{c|}{ Units } \\
\hline Algae pond size & 1000 & acres \\
\hline Algae productivity & 33 & g/m2/day \\
\hline Influent flow & 14 million & gallons/day \\
\hline
\end{tabular}

\subsection{ENGINEERING METHODOLOGY}

Conventional fluid flow equations for pipes [13] are used to size the pipeline diameter. Conventional pump hydraulic equations are used to size the pump and motor and to calculate energy (electricity) [14] requirements.

Similar to results of an analysis of gas flow of $\mathrm{CO}_{2}$-containing gases co-located with algae cultivation [15][16], a driving parameter of cost and cost-effective distance is the diameter of the pipe. The larger the diameter, the more expensive is the pipe, but the lower the pressure drop along the pipe. This larger diameter results in a lower-power pumping requirement than for a narrower pipe. An example is shown in Figure 2. Although the capital cost can be minimized for this example by selecting an intermediate pipe diameter, all cases in this analysis use a relatively larger steel pipe to minimize the pump size and energy 
requirement, at the expense of purchasing a larger pipe. Minimizing the electricity requirement to operate the pump also minimizes greenhouse gas emissions in a life-cycle analysis (LCA). Pipe diameters range from 25 to 30 inches, as the pipe length ranges from 1 to 10 miles. The efficiency of the combined pump/motor is assumed to be $63 \%$ [13].

\section{Wastewater transport costs - 10 miles}

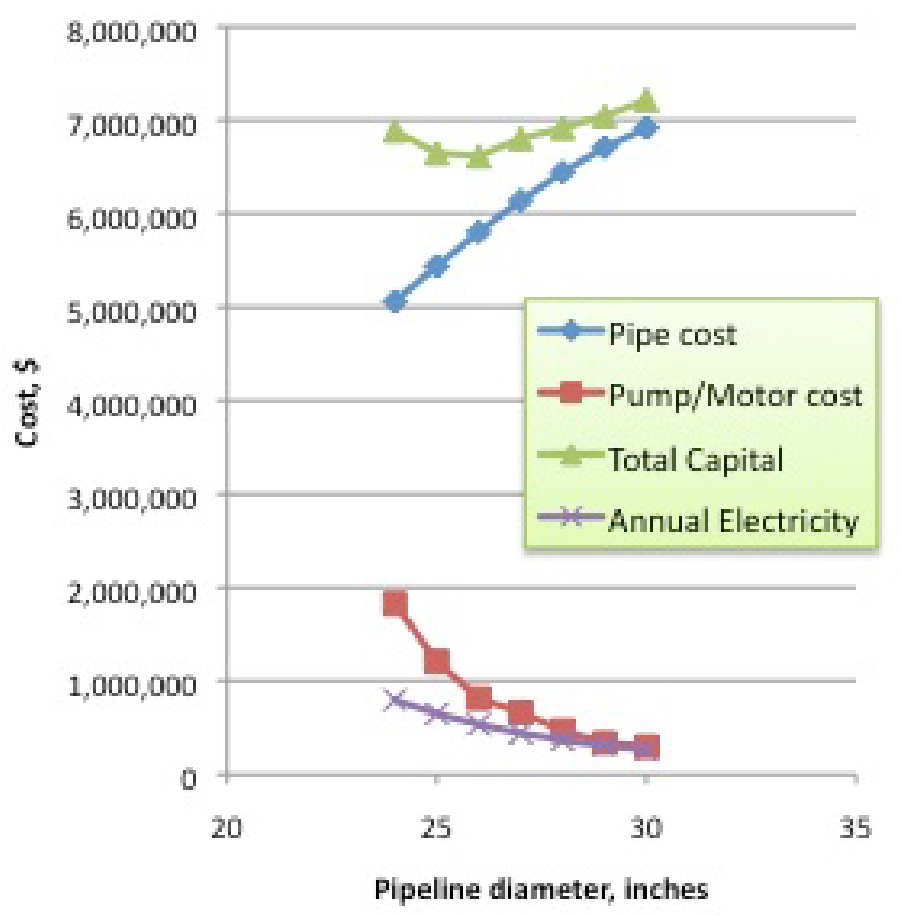

Figure 2. The tradeoff between cost of pipe and cost of pump/motor and electricity for a 10-mile transport system depends on diameter of pipeline.

\subsection{ECONOMIC ANALYSIS}

The capital cost of the pipe and pump/motor are estimated from engineering handbooks [17]. Electricity to operate the pump is calculated at 8 cents/kWh, as in the related $\mathrm{CO}_{2}$ transport analysis [15].

The cost of the pipeline system is compared with the avoided cost of purchased nutrients $\mathrm{N}$ and $\mathrm{P}$, from anhydrous ammonia $\left(\mathrm{NH}_{3}\right)$ and diammonium phosphate (DAP), respectively. The cost of the nutrients is derived from estimates in Davis et al. [18] for large-scale algae production. Davis et al. assumed a productivity value for the algae of $25 \mathrm{~g} / \mathrm{m}^{2} /$ day, whereas Lundquist et al. assumed a high value of 33 $\mathrm{g} / \mathrm{m} 2 /$ day [11]. The nutrient requirements were adjusted accordingly for this analysis. Under these assumptions, the annual cost of nutrients is $\$ 1.15$ million dollars.

This analysis does not assume any return of nutrients to the ponds following downstream processing, which may be possible [11] and would reduce the annual nutrient requirements, and piping or purchased nutrients.

Annual costs for operation of the transport system, compared with the cost of nutrients, are considered for a 30-year system lifetime. This lifetime is typically assumed for capital-intensive projects, such as wastewater facilities. Cost assumptions are listed in Table 2. 
Table 2. Cost and Economic Assumptions

\begin{tabular}{|l|l|l|}
\hline \multicolumn{1}{|c|}{ Parameter } & \multicolumn{1}{c|}{ Value/Units } & \multicolumn{1}{c|}{ Reference } \\
\hline Pipe cost & $\$ 430 / \mathrm{m}$ for 30-inch pipe & [17] adjusted to 2017 dollars \\
\hline Electricity & 8 cents $/ \mathrm{kWh}$ & \\
\hline $\mathrm{NH}_{3}$ & $0.1908 \$ / \mathrm{kg}$ & [18] adjusted to 2017 dollars \\
\hline $\mathrm{DAP}$ & $0.1557 \$ / \mathrm{kg}$ & [18] adjusted to 2017 dollars \\
\hline Capital charge & $10 \% /$ year & \\
\hline
\end{tabular}

\section{RESULTS}

The results of the analysis are presented as savings for building the pipeline, compared with the avoided cost of nutrients. Figure 3 indicates these savings for the Lundquist base case [11] for pipeline distance up to 10 miles. Beyond 10 miles, the savings are minimal.

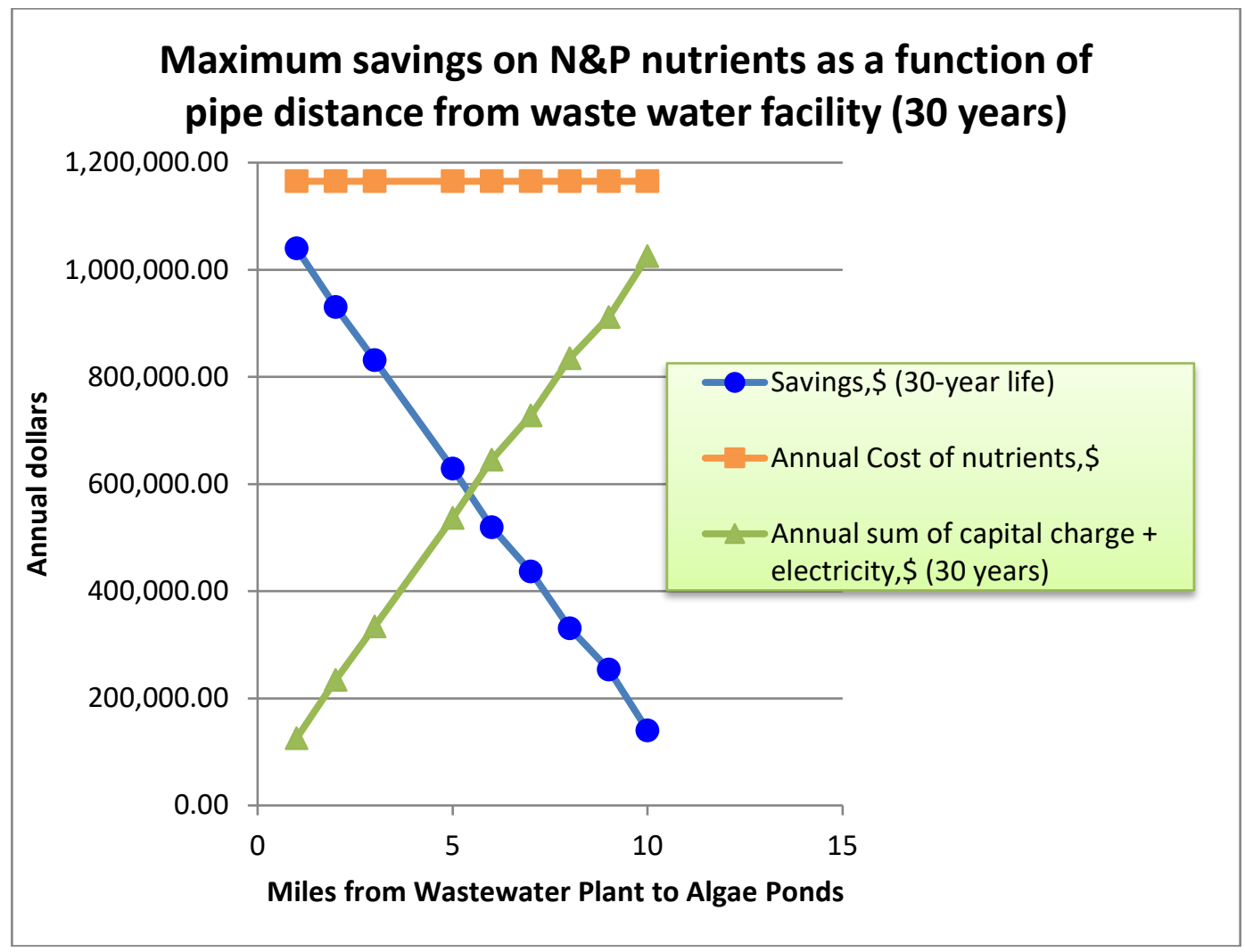

Figure 3. Savings results for using replacing purchased nutrients with municipal wastewater for a 30-year system

A sensitivity comparison was also calculated to compare the 30-year lifetime with a 20-year lifetime, as the lifetime of the algae pond is not well established. This comparison is shown in Figure 4. Although the 
savings for the shorter-lived system are lower, the difference between the savings for different lifetime assumptions is small. The cost of electricity dominates the annual cost in either case.

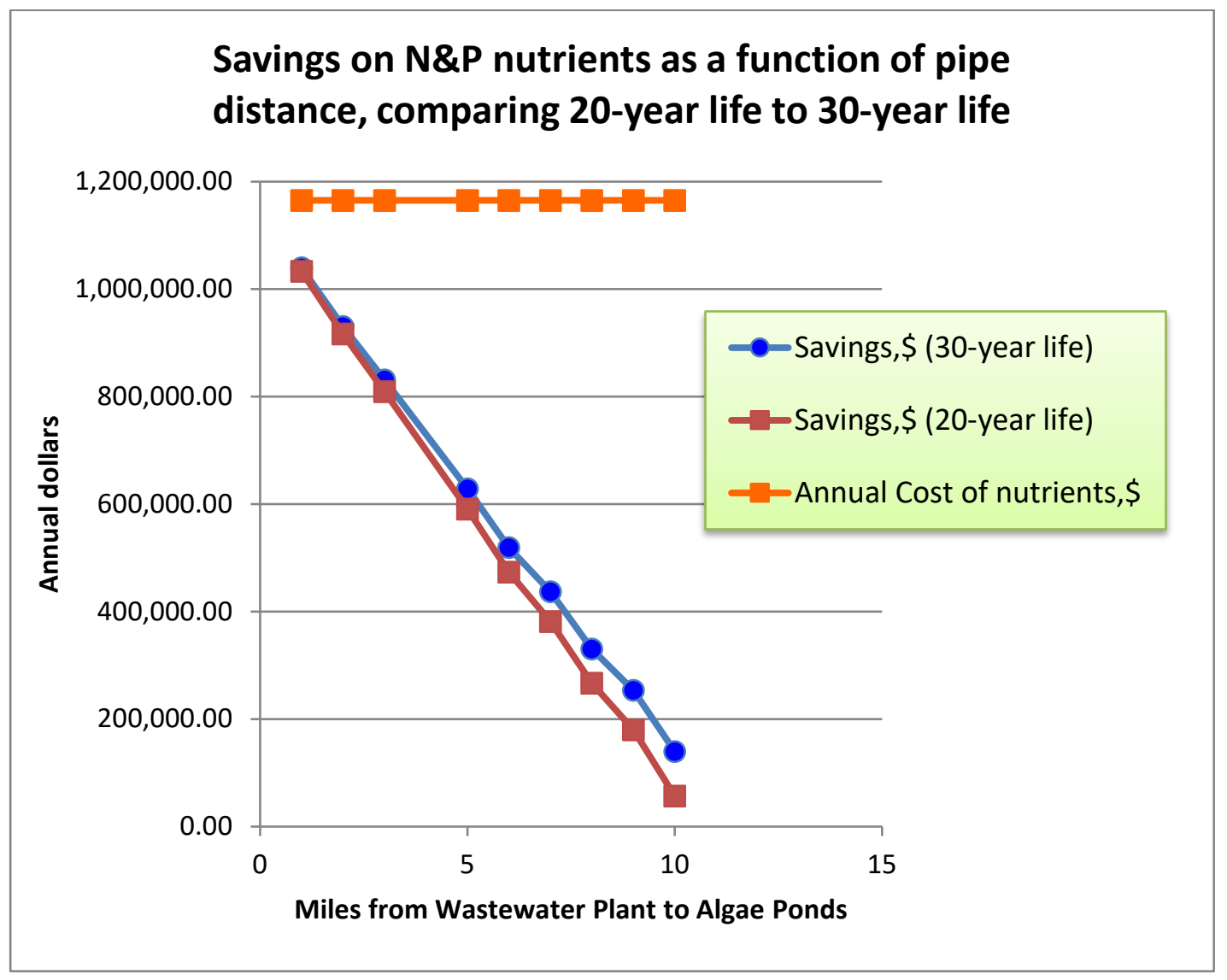

Figure 4. Cost comparison between 20-year system and 30-year system that replaces purchased nutrients with municipal wastewater as a source of nutrients for open-pond algae production.

\section{DISCUSSION}

Cost savings are needed before commercial production of algae for fuel and other bioproducts is economically viable. Savings of over \$1 million dollars per year on the purchase of nitrogen and phosphorus compounds are possible for 1000-acre algae open-pond cultivation systems that make use of MWW to provide these nutrients. Under our assumptions, this savings occurs at a distance of one mile or less between the wastewater plant and the algae facility. This cost savings offsets the cost of the pipeline system that transports the wastewater to the ponds. The greater the distance is between the wastewater and the algae ponds, the lower are these savings.

Compared to the overall cost (capital and operating expenses) of the algae facility, this is a small savings. Compared to the annual operating cost of approximately \$9 million dollars for the 1000 acres of cultivation ponds [Ref 11, page 40], the use of $\mathrm{N}$ and $\mathrm{P}$ from MWW is significant and important for reducing the cost of the algae bioproducts. 


\section{ACKNOWLEDGMENTS}

The authors would like to thank Dr. John Benemann of MicroBio Engineering, Inc., for helpful discussions related to this study. Matthew Langholtz provided extensive review comments on an earlier version of this manuscript. This research was supported by the U.S. Department of Energy (DOE) under the Bioenergy Technologies Office, and we thank Devinn Lambert for her sponsorship and guidance. Oak Ridge National Laboratory is managed by UT-Battelle, LLC, for DOE under contract DE-AC0500OR22725. The views and opinions of the authors expressed herein do not necessarily state or reflect those of the United States Government or any agency thereof. Neither the United States Government nor any agency thereof, nor any of their employees, makes any warranty, expressed or implied, or assumes any legal liability or responsibility for the accuracy, completeness, or usefulness of any information, apparatus, product, or process disclosed, or represents that its use would not infringe privately owned rights.

\section{REFERENCES}

1. Lundquist TJ (2008) Production of algae in conjunction with wastewater treatment. In: Proceedings of the $11^{\text {th }}$ International Conference on Applied Phycology, National University of Ireland, Galway, June 22-27.

2. A. Solimento, A., et al., "Integral microalgae-bacteria model (BIO-ALGAE): application to wastewater high rate algal ponds, Science of the Total Environment 601-602 (2017) 646-657.

3. Judd, S. J., "The cost benefit of algal technology for combined $\mathrm{CO}_{2}$ mitigation and nutrient abatement." Renewable and Sustainable Energy Reviews 71 (2017) 379-387.

4. Craggs, R., Sutherland, D. and Campbell, H., "Hectare-scale demonstration of high rate algal ponds for enhanced wastewater treatment and biofuel production.” J. Appl. Phycol. (2012) 24:329-337.

5. USGS Water Science School, "Problems with excess levels of nitrogen in the environment.

$<$ https://water.usgs.gov/edu/nitrogen.html $>$

6. United Nations Fisheries and Aquaculture Department < http://www.fao.org/fishery/en>

7. Oilgae, "Nutrients for Algae Growth.” <www.oilgae.com/ref/glos/nutrient_for_algae_growth.html>

8. Chiu, Y., and Wu, M., "Considering Water Availability and Wastewater Resources in the Development of Algal Bio-Oil,” Biofuels, Bioprod. Bioref. (2013) 7:406-415.

9. Posadas, E., Muñez, R.. and Guieyesse, B., "Integrating nutrient removal and solid management restricts the feasibility of algal biofuel generation via wastewater treatment," Algal Research (2017) 22:39-46.

10. Benemann, J., and Lundquist, T.J., “Multi-trophic Algal Municipal Wastewater Treatment,” Proc. Of the 6th International Conf. on Algal Biomass, Biofuels \& Bioproducts, 26-29 June 2016, San Diego, CA. Also found at <http://microbioengineering.com/wastewater/>

11. Lundquist, T. "Scale-up of Algal Biofuel Production Using Waste Nutrients.” Presentation to the US DOE Biotechnologies Office Peer Review, March 17, 2017.

<https://energy.gov/sites/prod/files/2017/05/f34/algae_lundquist_135240.pdf>

12. United States Environmental Protection Agency, Primer for Municipal Wastewater Systems. EPA Report Number 832-R-04-001, September 2004.

13. Vennard, J. K., and Street R., L., Elementary Fluid Mechanics (Fifth Edition). John Wiley \& Sons: New York. 1975. 
14. Hydraulic Pump Power Calculations. http://www.engineeringtoolbox.com/pumps-power-d_505.html

15. Efroymson, R., Coleman A., Wigmosta, M., Schoenung, S., Sokhansanj, S., Langholtz, M., Davis, R., Microalgae. In. U.S. Department of Energy. 2016 Billion-Ton Report: Advancing Domestic Resources for a Thriving Bioeconomy, Volume 1: Economic Availability of Feedstocks. M. H. Langholtz, B. J. Stokes, and L. M. Eaton (Leads), ORNL/TM-2016/160. Oak Ridge National Laboratory, Oak Ridge, TN. 448p., 2016.

16. Schoenung, S. M., et al., "Algae Co-location Resources of Carbon Dioxide and Effective Transport Distances,” Poster presentation, Algae Biomass Organization 2016 Summit, Glendale, AZ, October 2016.

17. Peters, Max S., Timmerhause, K. D., and West, R. E., Plant Design and Economics for Chemical Engineers (Fifth Editions). McGraw Hill: New York. 2003.

18. Davis, R., Markham, J., Kinchin, C., Grundl, N., Tan, E. C. D., Humbird, D., Process Design and Economics for the Production of Algal Biomass: Algal Biomass Production in Open Pond Systems and Processing through Dewatering for Downstream Conversion. NREL/TP-5100-64772. National Renewable Energy Laboratory, Golden, CO, February 2016. 